Nevada

Environmental

Restoration

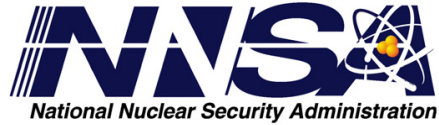

Project

Addendum 2 to the Streamlined Approach for Environmental Restoration Closure Report for Corrective Action Unit 454: Historical Underground Storage Tank Release Sites, Nevada Test Site, Nevada

Controlled Copy No.:

Revision No.: 0

May 2009

Approved for public release; further dissemination unlimited.

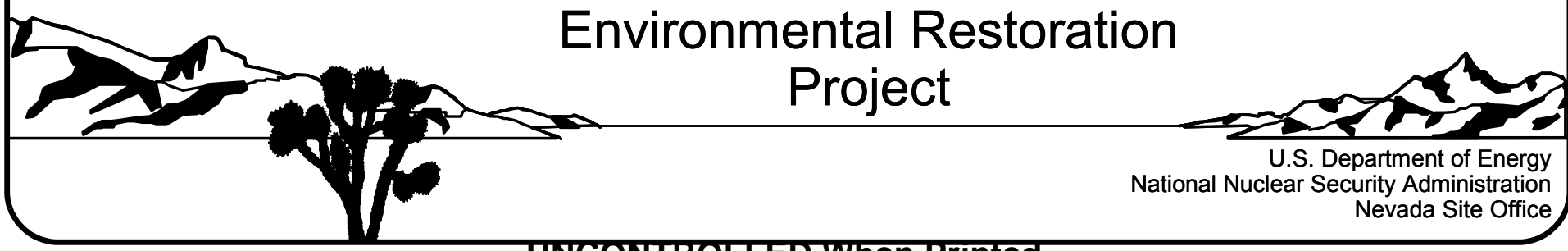


Available for public sale, in paper, from:

U.S. Department of Commerce

National Technical Information Service

5285 Port Royal Road

Springfield, VA 22161

Phone: 800.553 .6847

Fax: 703.605.6900

Email: orders@ntis.gov

Online ordering: http://www.ntis.gov/ordering.htm

Available electronically at $\underline{h t p: / / w w w . o s t i . g o v / b r i d g e ~}$

Available for a processing fee to U.S. Department of Energy and its contractors, in paper, from:

U.S. Department of Energy

Office of Scientific and Technical Information

P.O. Box 62

Oak Ridge, TN 37831-0062

Phone: 865.576 .8401

Fax: 865.576.5728

Email: reports@adonis.osti.gov

Reference herein to any specific commercial product, process, or service by trade name, trademark, manufacturer, or otherwise, does not necessarily constitute or imply its endorsement, recommendation, or favoring by the United States Government or any agency thereof or its contractors or subcontractors. 


\title{
ADDENDUM 2 TO THE STREAMLINED APPROACH FOR ENVIRONMENTAL RESTORATION CLOSURE REPORT FOR CORRECTIVE ACTION UNIT 454: HISTORICAL UNDERGROUND STORAGE TANK RELEASE SITES, NEVADA TEST SITE, NEVADA
}

\author{
U.S. Department of Energy \\ National Nuclear Security Administration \\ Nevada Site Office \\ Las Vegas, Nevada
}

Controlled Copy No.:

Revision No.: 0

May 2009

Approved for public release; further dissemination unlimited.

Reviewed and determined to be UNCLASSIFIED.

Derivative Classifier: Joseph Johnston, SNJV Classification Officer

Signature: /s/Joseph J Jame/persona

Date: $5 / 11 / 2009$ 


\section{Addendum 2 to the Streamlined Approach for Environmental Restoration Closure Report for Removal of the Use Restriction}

This document constitutes an addendum to the Streamlined Approach for Environmental Restoration Closure Report for Corrective Action Unit 454: Historical Underground Storage Tank Release Sites, Nevada Test Site, Nevada, April 1998 as described in the document Supplemental Investigation Report for FFACO Use Restrictions, Nevada Test Site, Nevada (SIR) dated November 2008. The SIR document was approved by NDEP on December 5, 2008. The approval of the SIR document constituted approval of each of the recommended UR removals. In conformance with the SIR document, this addendum consists of:

- This page that refers the reader to the SIR document for additional information

- The cover, title, and signature pages of the SIR document

- The NDEP approval letter

- The corresponding section of the SIR document

This addendum provides the documentation justifying the cancellation of the URs for CASs:

- 12-25-08, Spill H950524F (from UST 12-B-1)

- 12-25-10, Spill H950919A (from UST 12-COMM-1)

These URs were established as part of Federal Facility Agreement and Consent Order (FFACO) corrective actions and were based on the presence of contaminants at concentrations greater than the action levels established at the time of the initial investigation (FFACO, 1996).

Since these URs were established, practices and procedures relating to the implementation of risk-based corrective actions (RBCA) have changed. Therefore, these URs were re-evaluated against the current RBCA criteria as defined in the Industrial Sites Project Establishment of Final Action Levels (NNSA/NSO, 2006). This re-evaluation consisted of comparing the original data (used to define the need for the URs) to risk-based final action levels (FALs) developed using the current Industrial Sites RBCA process.

The re-evaluation resulted in a recommendation to remove these URs because contamination is not present at these sites above the risk-based FALs. Requirements for inspecting and maintaining these URs will be canceled, and the postings and signage at each site will be removed. Fencing and posting may be present at these sites that are unrelated to the FFACO URs such as for radiological control purposes as required by the NV/YMP Radiological Control Manual (NNSA/NSO, 2004). This modification will not affect or modify any non-FFACO requirements for fencing, posting, or monitoring at these sites.

\section{References}

DOE/NV, see U.S. Department of Energy, Nevada Operations Office. 
FFACO, see Federal Facility Agreement and Consent Order.

Federal Facility Agreement and Consent Order. 1996 (as amended). Agreed to by the State of Nevada, U.S. Department of Energy, and U.S. Department of Defense.

NNSA/NSO, see U.S. Department of Energy, National Nuclear Security Administration Nevada Site Office.

U.S. Department of Energy, Nevada Operations Office. 1998. Streamlined Approach for Environmental Restoration Closure Report for Corrective Action Unit 454 Historical Underground Storage Tank Release Sites, Tank Release Sites, Nevada Test Site, Nevada, Rev. 0, DOE/NV/11718-211. April. Las Vegas, NV.

U.S. Department of Energy, National Nuclear Security Administration Nevada Site Office. 2004. NV/YMP Radiological Control Manual, DOE/NV/11718--079, Rev. 5. Prepared by Bechtel Nevada. Las Vegas, NV.

U.S. Department of Energy, National Nuclear Security Administration Nevada Site Office. 2006. Industrial Sites Project Establishment of Final Action Levels, Rev. 0, DOE/NV--1107. Las Vegas, NV.

U.S. Department of Energy, National Nuclear Security Administration Nevada Site Office. 2008. Supplemental Investigation Plan for FFACO Use Restrictions, Nevada Test Site, Nevada, Rev. 0, DOE/NV--1256. Las Vegas, NV. 
Nevada

Environmental

Restoration

Project

Supplemental Investigation Report for

FFACO Use Restrictions

Nevada Test Site, Nevada

Controlled Copy No::

Revision No.: 0

November 2008

Approved for public release; further dissemination unlimited.

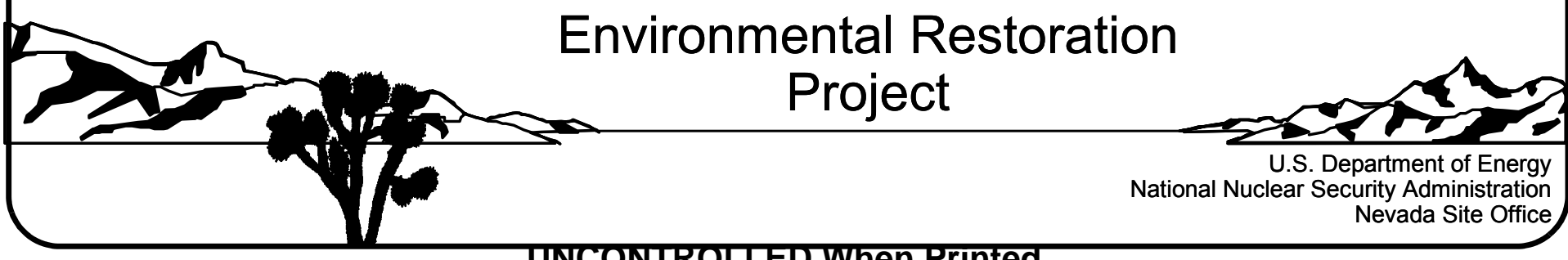




\section{SUPPLEMENTAL INVESTIGATION REPORT FOR FFACO USE RESTRICTIONS NEVADA TEST SITE, NEVADA}

U.S. Department of Energy

National Nuclear Security Administration

Nevada Site Office

Las Vegas, Nevada

Controlled Copy No.:

Revision No.: 0

Reviewed and determined to be UNCLASSIFIED.

This review does not constitute clearance for public release.

Derivative Classifier: Joseph Johnston, CO

Signature: /s/Joseph Johnston

Date: $11 / 24 / 20,08$

November 2008

Approved for public release; further dissemination unlimited. 


\section{SUPPLEMENTAL INVESTIGATION REPORT FOR FFACO USE RESTRICTIONS: NEVADA TEST SITE, NEVADA}

Approved by: /S/Kevin J. Cabble

Date: $11 / 12 / 2008$

Kevin J. Cabble

Federal Sub-Project Director

Industrial Sites Sub-Project

Approved by: /S/ Robert F. Boehlecke

Date: $11 / 12 / 2008$

Robert F. Boehlecke

Federal Project Director

Environmental Restoration Project 


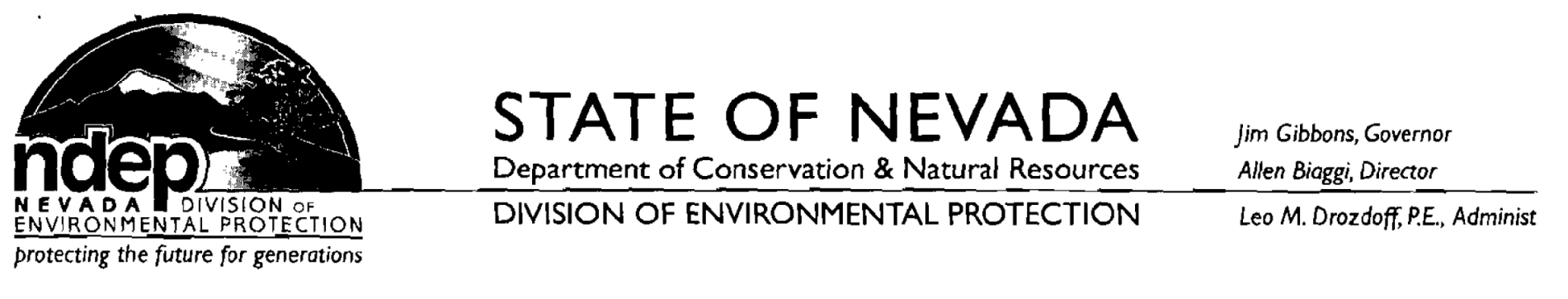

December 5, 2008

Robert F. Boehlecke

Federal Project Director

Environmental Restoration Project

National Nuclear Security Administration

Nevada Site Office

P. O. Box 98518

Las Vegas, NV 89193-8518

RE: Approval of Final Supplemental Investigation Report for FFACO Use Restrictions Nevada Test Site and Tonopah Test Range, Nevada, Revision 0, November 2008 Federal Facility Agreement and Consent Order

Dear Mr. Boehlecke:

The Nevada Division of Environmental Protection, Bureau of Federal Facilities (NDEP) staff has received and reviewed the submittal of the Final Supplemental Investigation Report for FFACO Use Restrictions, Nevada Test Site and Tonopah Test Range, Nevada, Revision 0 , November 2008. The report is hereby approved without comments pursuant to Subpart XII.8.a of the Federal Facility Agreement and Consent Order (FFACO).

Address any questions regarding this matter to either Ted Zaferatos at (702) 486-2850, ext. 234, Jeff MacDougall at (702) 486-2850, ext. 233, or me at (702) 486-2850, ext. 231.

Sincerely,

/s/Chris Andres for

T.H. Murphy

Chief

Bureau of Federal Facilities
ACTION

INFO

NSO/MGR

AMBCM

AMEM

AMNS

AMSO

AMSS

COR-RAI-

File Code 
Robert F. Boehlecke

Page 2

December 5, 2008

JJM $/ T Z$

cc: $\quad$ K. J. Cabble, ERP, NNSA/NSO, Las Vegas, NV

E.F. DiSanza, WMP, NNSA/NSO

FFACO Group, PSG, NNSA/NSO, Las Vegas, NV

Jeffrey Fraher, DTRAVCXT, Kirkland AFB, NM

W.R. Griffin, SNJV/DTRA, M/S 645, Mercury, NV

T.A. Thiele, NSTec, Las Vegas, NV

John Wong, Dennis Nicodemus, Kevin Campbell, NDEP Las Vegas, NV 
Table 4-14

Sample Results for SVOCs Detected above Minimum

Detectable Concentrations at UR 25-25-15

\begin{tabular}{|c|c|c|c|c|c|c|}
\hline \multirow[b]{2}{*}{$\begin{array}{c}\text { Sample } \\
\text { Location }\end{array}$} & \multirow[b]{2}{*}{$\begin{array}{l}\text { Sample } \\
\text { Number }\end{array}$} & \multirow[b]{2}{*}{$\begin{array}{l}\text { Depth } \\
\text { (ft bgs) }\end{array}$} & \multicolumn{4}{|c|}{ Contaminants of Potential Concerns (mg/kg) } \\
\hline & & & 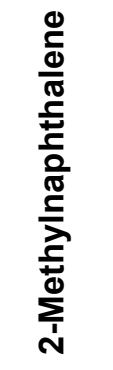 & $\begin{array}{l}\frac{0}{0} \\
\text { J } \\
\frac{0}{\pi} \\
0\end{array}$ & 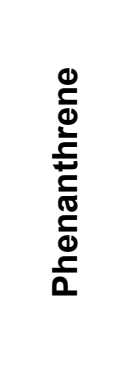 & 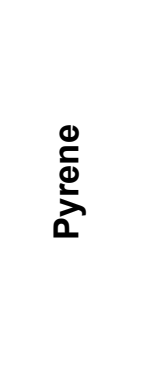 \\
\hline \multicolumn{3}{|c|}{ Final Action Levels $^{a}$} & 190 & 86 & 100,000 & 100,000 \\
\hline \multirow{2}{*}{ K01 } & $452 K 001$ & $34.5-35.0$ & 1.14 & -- & 1.44 & 0.0816 \\
\hline & $452 \mathrm{~K} 002$ & $34.5-35.0$ & 0.0451 & 0.186 & 1.57 & -- \\
\hline
\end{tabular}

${ }^{a} B a s e d$ on U.S. Environmental Protection Agency, Regional Screening Levels for Chemical Contaminants at Superfund Sites (EPA, 2008a).

bgs $=$ Below ground surface

-- = Not detected above minimum detectable concentrations. $\mathrm{ft}=$ Foot

$\mathrm{mg} / \mathrm{kg}=$ Milligrams per kilogram

\subsection{CAU 454, CAS 12-25-08 - Spill H950524F (from UST 12-B-1)}

\subsubsection{CAS Description}

Corrective Action Site 12-25-08 consists of a subsurface petroleum hydrocarbon release from the UST located at the "B" Tunnel in Area 12. The UST was located east of the main portal entrance to "B" Tunnel. The approximate 500-gal capacity tank contained approximately $400 \mathrm{gal}$ of diesel fuel at the time of identification. The tank was situated on a hillside slope and was partially exposed at the surface. On March 1, 1995, the tank was removed and hydrocarbon releases associated with the tank were included in CAS 12-25-08. The CAS was subjected to corrective actions that resulted in the implementation of a UR for TPH contamination (DOE/NV, 1998c).

\subsubsection{Current Use Restriction Description}

A UR is in place at the site due to TPH contamination. The UR, as described in the FFACO, states the future use of land related to this CAU, as described by surveyed location, is restricted from any activity that may alter or modify the containment control, as identified by the state and in the CR or 
other CAU documentation, unless appropriate concurrence is obtained in advance. Monitoring requirements have not been identified for the site.

\subsubsection{Basis for Current Use Restriction}

Of the two original samples collected, one taken at the east side of the excavation, with a TPH diesel concentration of $490 \mathrm{mg} / \mathrm{kg}$, exceeded the action level of $100 \mathrm{mg} / \mathrm{kg}$; therefore, a UR was implemented. A second sample taken at the west side of the excavation had a TPH diesel level of $92 \mathrm{mg} / \mathrm{kg}$, which is below the action level (DOE/NV, 1998c).

\subsubsection{Basis for Use Restriction Modification}

One new environmental sample was collected at CAS 12-25-08 according to the sampling plan (NNSA/NSO, 2008) and analyzed for VOCs and SVOCs in which the hazardous constituents of TPH are reported. Table 4-15 presents the VOC results that were detected above the MDCs. None of the SVOCs were detected above MDCs.

The analytical results were evaluated using the RBCA process (NNSA/NSO, 2006) in which the individual results of contaminants (detected above the MDCs) were compared to the FALs. None of the hazardous constituents of TPH were identified above their respective FALs; therefore, there are no COCs present at this site. 
Table 4-15

Sample Results for VOCs Detected above Minimum

Detectable Concentrations at UR 12-25-08

\begin{tabular}{|c|c|c|c|c|c|c|c|c|}
\hline \multirow[b]{2}{*}{ 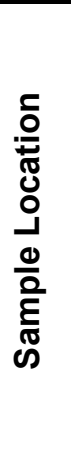 } & \multirow[b]{2}{*}{ 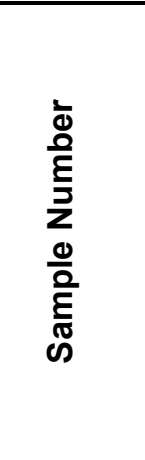 } & \multirow[b]{2}{*}{ 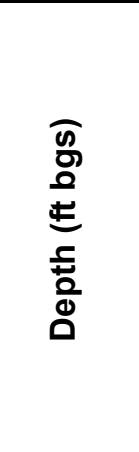 } & \multicolumn{6}{|c|}{ Contaminants of Potential Concern (mg/kg) } \\
\hline & & & 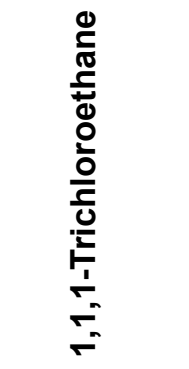 & $\begin{array}{l}\text { 은 } \\
\frac{0}{0} \\
\frac{0}{0} \\
\frac{0}{c}\end{array}$ & 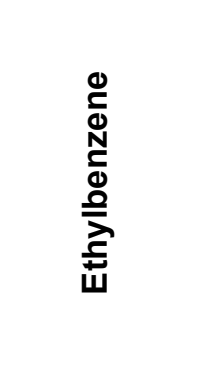 & 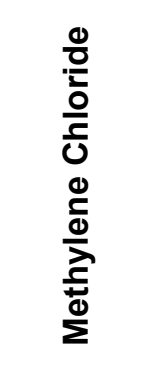 & $\frac{\stackrel{0}{c}}{\stackrel{0}{\frac{D}{0}}}$ & 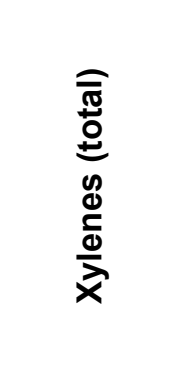 \\
\hline \multicolumn{3}{|c|}{ Final Action Levels ${ }^{a}$} & 1,200 & 0.47 & 400 & 21 & 520 & 420 \\
\hline E01 & 454E001 & $0.0-0.5$ & $0.00176(\mathrm{~J})$ & $0.000849(\mathrm{~J})$ & $0.000755(\mathrm{~J})$ & $0.0505(\mathrm{~J})$ & $0.00299(\mathrm{~J})$ & $0.00317(\mathrm{~J})$ \\
\hline
\end{tabular}

${ }^{a}$ Based on U.S. Environmental Protection Agency, Regional Screening Levels for Chemical Contaminants at Superfund Sites (EPA, 2008a).

bgs $=$ Below ground surface

$\mathrm{ft}=$ Foot

$\mathrm{J}=$ Estimated value

$\mathrm{mg} / \mathrm{kg}=$ Milligrams per kilogram 


\subsubsection{Recommended Modification}

Remove the FFACO UR, signage, and associated inspection and maintenance requirements from this site.

\subsection{CAU 454, CAS 12-25-10 - Spill H950919A (from UST 12-COMM-1)}

\subsubsection{CAS Description}

Corrective Action Site 12-25-10 consists of a subsurface petroleum hydrocarbon release located at the former Communications/Power Maintenance Shop in Area 12. The UST was located north of a former communications building and was approximately 50 percent exposed at the time of identification. The approximate 500-gal tank was used to store waste oil hydrocarbons. On August 7, 1995, the tank and associated hydrocarbon releases were included in CAS 12-25-10. The tank was removed and, during removal and excavation of surrounding soils, a lens of gray material was identified and attributed to an earlier release. Additional excavation was completed on December 19, 1997; however, the gray lens remained visible. This resulted in the implementation of a UR for TPH contamination (DOE/NV, 1998c).

\subsubsection{Current Use Restriction Description}

A UR is in place at the site due to TPH contamination. The UR, as described in the FFACO, states the future use of land related to this CAU, as described by surveyed location, is restricted from any activity that may alter or modify the containment control, as identified by the state and in the CR or other CAU documentation, unless appropriate concurrence is obtained in advance. Monitoring requirements have not been identified for the site.

\subsubsection{Basis for Current Use Restriction}

Samples taken from CAS 12-25-10 were analyzed for TPH-oil, Toxicity Characteristic Leaching Procedure metals, and PCBs. Based on the results, TPH is the only COC present. Concentrations of $\mathrm{TPH}$, exceeding the action level of $100 \mathrm{mg} / \mathrm{kg}$, were detected in six of eight samples. These samples were from a lens of gray material visible in the excavation and attributed to an earlier release. Additional excavation was performed after samples were taken, and the lens of gray material was still visible in remaining soils; therefore, a UR was implemented. Table 4-16 contains analytical results 
for soil samples taken before excavation (DOE/NV, 1998c). Although these soils were removed, it is assumed that the remaining gray lens material has similar concentrations.

Table 4-16

Sample Results for the Basis of UR 12-25-10

\begin{tabular}{|c|c|c|}
\hline \multirow{2}{*}{$\begin{array}{c}\text { Sample } \\
\text { Identification }\end{array}$} & \multirow{2}{*}{$\begin{array}{l}\text { Depth } \\
\text { (ft bgs) }\end{array}$} & TPH - Oil (mg/kg) \\
\hline & & $\begin{array}{l}\text { Action Level } \\
100 \mathrm{mg} / \mathrm{kg}\end{array}$ \\
\hline 12-COMM-1/N. Wall & 3 & 1,600 \\
\hline 12-COMM-1/N. Btm & 6 & 120 \\
\hline 12-COMM-1/E. Wall & 3 & 740 \\
\hline 12-COMM-1/W. Wall & 3 & 1,200 \\
\hline 12-COMM-1/S. Wall & 3 & 1,800 \\
\hline 12-COMM-1/S. Btm & 6 & 600 \\
\hline
\end{tabular}

Note: Bold text indicates value exceeding the action level.

bgs $=$ Below ground surface

$\mathrm{ft}=$ Foot

$\mathrm{mg} / \mathrm{kg}=$ Milligrams per kilogram

$\mathrm{TPH}=$ Total petroleum hydrocarbons

\subsubsection{Basis for Use Restriction Modification}

One new environmental sample was collected from CAS 12-25-10 according to the sampling plan (NNSA/NSO, 2008) and analyzed for VOCs and SVOCs in which the hazardous constituents of TPH are reported. Table 4-17 presents the VOC results that were detected above the MDCs. None of the SVOCs were detected above MDCs.

The analytical results were evaluated using the RBCA process (NNSA/NSO, 2006) in which the individual results of contaminants (detected above the MDCs) were compared to the FALs. None of the hazardous constituents of TPH were identified above their respective FALs; therefore, there are no COCs present at this site. 
Table 4-17

Sample Results for VOCs Detected above Minimum

Detectable Concentrations at UR 12-25-10

\begin{tabular}{|c|c|c|c|}
\hline $\begin{array}{c}\text { Sample } \\
\text { Location }\end{array}$ & $\begin{array}{c}\text { Sample } \\
\text { Number }\end{array}$ & $\begin{array}{c}\text { Depth } \\
\text { (ft bgs) }\end{array}$ & Contaminants of Potential Concern (mg/kg) \\
\cline { 3 - 4 } & Final Action Levels & Tetrachloroethylene \\
\hline F02 & $454 F 001$ & $2.0-2.5$ & 1.3 \\
\hline
\end{tabular}

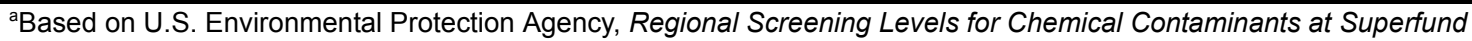
Sites (EPA, 2008a).

bgs $=$ Below ground surface $\mathrm{ft}=$ Foot

$\mathrm{mg} / \mathrm{kg}=$ Milligrams per kilogram

\subsubsection{Recommended Modification}

Remove the FFACO UR, signage, and associated inspection and maintenance requirements from this site.

\subsection{CAU 1010, CAS PRL 454 - Weathered Diesel Fuel}

\subsubsection{CAS Description}

Corrective Action Site PRL 454 consists of a subsurface petroleum hydrocarbon release that was identified as surrounding two concrete pads that had previously supported two diesel generators at the former Microwave Relay Annex, located on Shoshone Peak, in Area 29. In 1994, the site was partially dismantled and the ASTs that supplied fuel to the generators were removed. The site is currently occupied by a 2,100-gal fuel tank, an antenna tower, and a U.S. Geological Survey equipment shed. Hydrocarbon spills associated with the generators were included in PRL 454. The CAS was subsequently subjected to corrective actions that resulted in the implementation of a UR for TPH contamination (Lockheed Martin Energy Systems, Inc., 1998).

\subsubsection{Current Use Restriction Description}

A UR is in place at the site due to TPH contamination. The UR, as recorded in the FFACO, states the future use of land related to this CAU, as described by surveyed location, is restricted from DOE or U.S. Air Force activity that may alter or modify the containment control, as identified by the state and 


\section{References}

DOE/NV, see U.S. Department of Energy, Nevada Operations Office.

EPA, see U.S. Environmental Protection Agency.

FFACO, see Federal Facility Agreement and Consent Order.

Federal Facility Agreement and Consent Order. 1996 (as amended February 2008). Agreed to by the State of Nevada; U.S. Department of Energy, Environmental Management; U.S. Department of Defense; and U.S. Department of Energy, Legacy Management.

Lockheed Martin Energy Systems, Inc. 1998. Environmental Compliance Program, Final UST Remedial Action Report: Phase 2 Offbase Excavate and Remove Sites. Hazardous Waste Remedial Actions Program. Prepared for the U.S. Department of Energy, Contract DE-AC05-84OR21400. July. Edwards Air Force Base, CA.

NNSA/NSO, see U.S. Department of Energy, National Nuclear Security Administration Nevada Site Office.

U.S. Department of Energy, National Nuclear Security Administration Nevada Site Office. 2004f. NV/YMP Radiological Control Manual, DOE/NV--11718-079, Rev. 5. Prepared by Bechtel Nevada. Las Vegas, NV.

U.S. Department of Energy, National Nuclear Security Administration Nevada Site Office. 2006. Industrial Sites Project Establishment of Final Action Levels, Rev. 0, DOE/NV--1107. Las Vegas, NV.

U.S. Department of Energy, National Nuclear Security Administration Nevada Site Office. 2008. Supplemental Investigation Plan for FFACO Use Restrictions, Nevada Test Site, Nevada, Rev. 0, DOE/NV--1256. Las Vegas, NV.

U.S. Department of Energy, Nevada Operations Office. 1998c. Streamlined Approach for Environmental Restoration Closure Report for Corrective Action Unit 454 Historical Underground Storage Tank Release Sites, Tank Release Sites, Nevada Test Site, Nevada, Rev. 0, DOE/NV/11718-211. April. Las Vegas, NV.

U.S. Environmental Protection Agency. 2008a. Regional Screening Levels for Chemical Contaminants at Superfund Sites. As accessed at http://epa-prgs.ornl.gov/chemicals/index.shtml on 27 July. Prepared by EPA Office of Superfund and Oak Ridge National Laboratory. 


\section{Library Distribution List}

\section{$\underline{\text { Copies }}$}

U.S. Department of Energy

1 (Uncontrolled, electronic copy)

National Nuclear Security Administration

Nevada Site Office

Technical Library

P.O. Box 98518, M/S 505

Las Vegas, NV 89193-8518

U.S. Department of Energy

1 (Uncontrolled, electronic copy)

Office of Scientific and Technical Information

P.O. Box 62

Oak Ridge, TN 37831-0062

Southern Nevada Public Reading Facility

2 (Uncontrolled, electronic copies)

c/o Nuclear Testing Archive

P.O. Box 98521, M/S 400

Las Vegas, NV 89193-8521

Manager, Northern Nevada FFACO

1 (Uncontrolled, electronic copy)

Public Reading Facility

c/o Nevada State Library \& Archives

100 N Stewart Street

Carson City, NV 89701-4285 